\title{
International cooperation in the investigation of sexual crimes against children
}

Міжнародна співпраця під час розслідування сексуальних злочинів щодо дітей

Received: March 3, 2021

Accepted: April 29, 2021

\begin{abstract}
Family, childhood, motherhood, and fatherhood are protected by the state. Any violence against and exploitation of a child is punishable by law. Parents should take care of their child's health, physical, spiritual, and moral development. However, society is increasingly facing sexual violence against minors. Insufficient response to sexual violence against minors is due to the latency of this type of crime, lack of awareness of proper prevention entities with the peculiarities of sexual violence against children, improper functioning of the mechanism of interaction, and international cooperation. Given the above, it is urgent to pay attention to the study of international cooperation in the investigation of sexual crimes against minors. The work aims to conduct a study of international cooperation in the investigation of sexual crimes against children. The subject of the research is public relations that arise, change, and end in the process of international cooperation in the investigation of sexual crimes against minors. The methodology of the study are such methods as historical-legal and comparative-legal; formal-logical; empirical; cognitive; method of analogy; and program-target. The study analyzes
\end{abstract}

Анотація

Сім'я, дитинство, материнство та батьківство знаходиться під захистом держави. Будь-яке насильство над дитиною та їі експлуатація караються законом. Батьки повинні піклуватися про здоров'я дитини, іiі фізичний, духовний та моральний розвиток. Однак, все частіше суспільство стикається 3 сексуальним насильством щодо дітей. Недостатня ефективність реагування на прояви сексуального насильства щодо дітей пов'язана 3 латентністю цього виду злочинів, браком обізнаності спеціальних суб'єктів запобігання 3 особливостями проявів сексуального насильства щодо дітей, неналежним функціонуванням механізму взаємодії та міжнародного співробітництва. 3 огляду на викладене, важливо приділити увагу дослідженню міжнародної співпраці під час розслідування сексуальних злочинів щодо дітей. Метою роботи є здійснення дослідження міжнародної співпраці під час розслідування сексуальних злочинів щодо дітей. Об'єктом дослідження є міжнародна співпраця під час розслідування сексуальних злочинів щодо дітей. Предметом дослідження $\epsilon$ суспільні відносини, що виникають, змінюються та припиняються в процесі міжнародної співпраці під час розслідування сексуальних злочинів щодо дітей.. Методологією дослідження складають такі

\footnotetext{
${ }^{49}$ Doctor of Law, Professor, Head of Department of Criminalistics and Criminal Process, University of the State Fiscal Service of Ukraine, Irpin, Ukraine.

${ }^{50}$ Doctor of Law, Professor, Honoured Master of Science and Technology of Ukraine, Professor of the Department of Public and Private Law, Borys Grinchenko Kyiv University, Ukraine.

${ }^{51} \mathrm{PhD}$ in Law, Associate Arofessor of Department of Criminalistics and Forensic Medicine, National Academy of Internal Affairs, Kyiv, Ukraine.

${ }^{52} \mathrm{PhD}$ in Law, senior teacher at the Department of Theory of State and Law, National Academy of Internal Affairs, Kyiv, Ukraine.

${ }^{53} \mathrm{PhD}$ in Law, teacher at the Department of Criminalistics and Forensic Medicine, National Academy of Internal Affairs, Kyiv, Ukraine.
} 


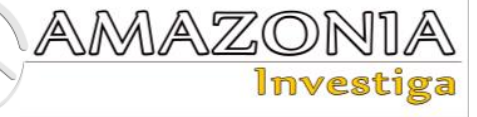

the specifics of cooperation between different foreign countries in the investigation of sexual crimes against children and identifies issues of such cooperation. Theoretical principles of prevention of sexual violence against minors have also been developed and scientifically substantiated criminological recommendations have been formed, which are important for further improvement of international cooperation and implementation of effective tools of such cooperation. establishing cooperation between Ukraine and foreign countries on sexual crimes against children.

Keywords: crime, punishment, sexual crimes against children, international cooperation, investigations, public relations. методи як історико-правовий та порівняльноправовий; формально-логічний; емпіричний; пізнавальний; метод аналогії; анкетування; програмно-цільовий. Результати дослідження. В результаті дослідження буде проаналізовано особливості співпраці між різними іноземними державами під час розслідування сексуальних злочинів щодо дітей та з'ясовано проблемні питання такої співпраці. Також розроблено теоретичні засади запобігання сексуальному насильству щодо дітей та сформовано науково обгрунтованих кримінологічних рекомендацій, що мають значення для подальшого вдосконалення міжнародної співпраці та впровадження дієвих інструментів такої співпраці та зроблено висновки, що для плідної міжнародної співпраці 3 досліджуваних питань існує необхідність прийняття нормативних актів, що сприятимуть налагодженню співробітництва України та іноземних держав щодо сексуальних злочинів щодо дітей.

Ключові слова: злочин, покарання, сексуальні злочини щодо дітей, міжнародна співпраця, розслідування, суспільні відносини.

Ukraine, but, as practice shows, it is still not efficient enough.

Violence is one of the main challenges of ou time. At the same time, in Ukraine, this issue, in particular regarding sexual violence against children, has been silenced for a long time. First of all, this is due to the ideological principles of the Soviet period, later - the cultural features, the mentality of a large part of Ukrainian society, when it was generally believed that the sphere of sexual intercourse can not be the property of the public. Meanwhile, the sexual violence experienced by a child has a negative effect on its further socialization. A child who has been sexually abused may later show cruelty, aggression, impulsiveness, prostitution, selfdestructive behavior, etc.

The legal recognition of human rights in the twentieth century occurred when the United Nations, in the grim shadow of the Holocaust, adopted the Universal Declaration of Human Rights in 1948 (Kharytonov, Kharytonova, Kolodin, \& Tkalych, 2020). With the development of democracy and the strengthening of the protection of human rights and freedoms, the importance and urgency of the comprehensive security of children from sexual violence have been reconsidered.

The development of comprehensive measures to prevent sexual violence against children is a priority in the current fight against violence in
To combat such forms of violence, the Council of Europe has adopted the most comprehensive legal instrument in this field, namely the Council of Europe Convention on the Protection of Children against Sexual Exploitation and Sexual Abuse, which aims to prevent sexual exploitation and sexual abuse of children; to protect children who have been victims of sexual offenses and to prosecute perpetrators.

Given the above, it is necessary to analyze the specifics of international cooperation in the investigation of sexual crimes against children, identify problematic aspects, and develop ways to solve problems and improve international cooperation.

\section{Theoretical Framework or Literature Review} sexual crimes against children has been studied by the following scientists: Schmidt (2010), Brych (2010), Humin (2009), Deryagin (2005), Zhuravel (2013), Galay (2014), Melnik, \& Khavronyuk (2018), Popov (2020), Romantsova (2013), and Tulyakov (2001); Chornous, Nikitina-Dudikova, Lepei, Antoniuk, and Fridman-Kozachenko (2021).
International cooperation in the investigation of 
Thus, Schmidt (2010) defined sexual violence against minors. Violence against minors, abuse, regardless of the needs of the child - a wide range of actions that harm the infant by people who care for him. These actions pose a serious threat to the child's health and safety, violating the infant's right to protection, support, and care from adults. The author also identifies several forms of child abuse: physical, psychological, and moral.

In addition, Brych (2010) analyzed crimes against sexual freedom and sexual integrity of a person under the laws of Ukraine and drew attention to the composition of the crime, the subjects who commit it, and the peculiarities of its regulation in Ukraine. The author has formed new approaches to defining the essence of such acts as rape, forcible gratification of sexual passion in an unnatural way, and other encroachments on sexual freedom and sexual integrity.

It should be stated, that Humin (2009) investigated the peculiarities of the criminological characteristics of a person in violent crimes. The author under criminal law violence means intentional socially dangerous and illegal influence carried out through physical or mental assault on other persons, as a result of which harm is caused or a real threat to life, health, honor, dignity, and other rights of citizens is created, which are provided and guaranteed by the Constitution and Laws of Ukraine.

Furthermore, Deryagin (2005) analyzed, in detail, the methods of prevention of sexual violence and drew attention to the fact that to prevent such violence it is necessary to take precautionary measures, namely to conduct educational activities on the issues under study. Moreover \& Zhuravel (2013) conducted sociopedagogical work on the prevention of violence against children. Likewise, Galay (2014) examined the international experience of preventing and combating domestic violence. The works of the author are the basis of this study.

The attention should be paid to the work of Popov (2020). He examined sexual exploitation and sexual violence against children using electronic means of communication and urgent countermeasures. Thus, the author believes that one of the ways to prevent and combat such offenses should be a broad information campaign to cover, in particular: children's rights and threats to them in the digital environment; information systems on governmental and non- governmental institutions and organizations that carry out activities in this area and can provide professional advice and assistance to victims; and national hotlines. According to the author, the development of specialized training programs for operatives and investigators of the National Police, the State Bureau of Investigation, the Security Service of Ukraine, judges, prosecutors, and lawyers is equally essential in combating violations of children's rights and freedoms. Thus, according to paragraph 109 of the annex to Recommendation CM / Rec (Council of Europe, 2018) 7, Member States need to allocate adequate resources and provide initial and continuing training for law enforcement officers, members of the judiciary, and professionals working with and for children. Conducting such training should contribute to improving knowledge about children's rights in the digital environment; preventing the risks that children face on the Internet; recognizing signals that a child may be the victim of online harm, violence, abuse, and exploitation, and taking steps to do so. In addition to specialized disciplines, which are taught directly in higher education institutions, according to the author, it is considered appropriate to conduct joint (interdepartmental) classes - training, seminars, round tables, etc. with the involvement of judges, prosecutors, lawyers, and investigators. Joint training will allow forming in these categories of participants the same vision of the problem, the existing practices of combating violent crimes against children with the use of electronic means of communication and digital systems.

It should be added, that Romantsova (2013) conducted a criminological description of persons who commit sexual violence against children. Thus, the researcher comprehensively developed theoretical principles of prevention of sexual violence against children and formulation of scientifically based criminological recommendations that are important for further improvement of this type of legal practice in Ukraine and identified the criminological content of the service method as a basic method of victimological influence; proved the expediency of systematization of forms of sexual violence against children, taking into account their medical and legal criteria, thus established the features of criminal forms of sexual violence, namely: transparent regulation of actions in the provisions of the Special Part of the Criminal Code of Ukraine (Law No. 2341-III, 2001); increased public danger; the generalized nature of the manifestation of violent sexual deviations (for example, the satisfaction of sexual desire in an unnatural way); combined into harmonious 


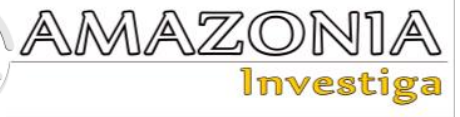

integrity of methods of assistance, persuasion, and protection. The author developed a criminological portrait of a person who commits sexual violence against a child, namely: a male person aged 18-35, a citizen of Ukraine, who is usually an acquaintance or relative of the victim, unemployed, with secondary or secondary special education. Such a person usually does not have a permanent sexual partner, or certain sexual deviations are observed, which mostly leads to the use of sexual violence against a child.

Finally, Tulyakov (2001) analyzed the problems of combating violent crime in Ukraine. Also, the researcher pays considerable attention to defining the prerequisites for the formation of criminal victimology as an independent scientific field, describes the basic concepts, principles, and scientific apparatus of victimology theory, and considers the fight against violent crime through the prism of victimology policy in society, identified prospects for criminal and preventive policies to limit victimization in Ukraine.

In addition, the study analyzed the comments of criminal procedure legislation, general textbooks on criminal law, analytical articles describing the features of protection of children from sexual exploitation and sexual violence, foreign experience in preventing violent crimes, and statistics on the state and structure of crime in Ukraine (Council of Europe, 2019; State Statistics Service of Ukraine, 2019; Tatsia, Borisova, \& Tyutyugina, 2015; Ministry of Internal Affairs of Ukraine, 2021).

Thus, from the above analysis of the literature, it can be concluded that the analysis of the investigation of sexual crimes against children is conducted by many scholars, but the attention to international cooperation in the investigation of such crimes is insufficient. Given this, there is a need to analyze in more detail the specifics of the investigation of crimes against children.

A large number of works by domestic and foreign scientists are devoted to the study of issues related to the research topic.

\section{Methodology}

Firstly, historical-legal and comparative-legal methods were used in the study to determine the state of research on the problem of sexual violence against children. Thus, this method allows us to understand that in different historical periods, attention to sexual violence against children has been paid differently. For example, in the Soviet period, this kind of violence was not studied and it was considered that it does not exist at all, while in 2014-2021 more and more attention is paid to the study of the research question. In particular, the comparative-legal method was used to analyze the legislation of individual European countries in the study area, as well as to identify the main areas of cooperation between these countries within international organizations.

What is more, the formal-logical method was used in the process of defining the concept of sexual violence against children and detailed interpretation of sexual crime. Using this method, a definition of the concept of sexual crime was provided, as well as existing definitions, were analyzed and attention was paid to their problematic issues and inconsistencies.

Further, the empirical method helped to clarify the problematic issues of legal practice in the investigation of crimes, prevention of sexual violence against children. Because of this method, the specifics of the investigation of crimes against children and the importance of international cooperation were clarified; and an algorithm of actions was developed to improve the current state of the research issue.

Additionally, the cognitive method was used to establish the specifics of forms of sexual violence and the characteristics of persons exposed to such violence and committing sexual crimes against children, as well as to justify the importance of using criminological knowledge in planning and implementing measures to prevent sexual violence against them.

Moreover, the method of analogy was used in formulating proposals for improving the forms and methods of interaction between the subjects of prevention of sexual violence against children and the commission of sexual crimes against them. This method helped to distinguish common features between sexual crimes against children and other violent crimes.

Finally, the program-targeted method was used to develop legislative changes to prevent the commission of sexual violence and sexual crimes against children. This method was used to comprehensively analyze existing programs and regulations, set goals for effective investigation of sexual crimes against children, and develop effective mechanisms for combating and international cooperation to identify, successfully investigate and prevent the recurrence of such crimes. 


\section{Results and Discussion}

\section{General provisions on sexual crimes against children in Ukraine}

The current legislation of Ukraine and increasing attention to combating sexual violence against children in Ukraine shows that our society today is not ready to comprehensively confront this negative phenomenon, and national legislation needs to be improved and brought closer to the best practices of other countries.

The main international document that regulates this issue is the Convention for the Protection of Human Rights and Fundamental Freedoms (United Nations, 1950) and the Convention on the Rights of the Child (United Nations, 1989).

In Ukrainian legislation, the main legal document is the Constitution of Ukraine (Law No. 254K/96BP, 1996). Among special legislation acts, the following should be mentioned: Criminal Code of Ukraine (Law No. 2341-III, 2001), On Child Protection (Law No. 2402-III, 2001), On Amendments to Certain Legislative Acts of Ukraine Concerning Counteraction to the Distribution of Child Pornography (Law No. 1819-VI, 2010), On prevention and counteraction to domestic violence (Law No. 2229-VIII, 2017), On Ensuring Equal Rights and Opportunities for Women and Men (Law No. 2866-IV, 2005), About the statement of the Instruction on the organization of activity of district police officers (Order No. 650, 2017), On the protection of public morality (Law No. 1296IV, 2003) etc.

In general, the Council of Europe Convention on the Protection of Children against Sexual Violence and Sexual Exploitation (CETS No. 201), adopted in October 2007, aims to:

a) preventing and combating sexual exploitation and sexual abuse of children;

b) protecting the rights of children who have been sexually exploited and sexually abused, and;

c) promoting national and international cooperation in combating sexual exploitation and sexual abuse of children.

The Annex to Recommendation CM / Rec (2018) 7 of the Committee of Ministers (Council of Europe, 2018) to member states on the principles of observance, protection, and realization of the rights of the child in the digital environment of 4 July 2018 (hereinafter - Recommendation CM / Rec (Council of Europe, 2018) 7) states that
These guidelines assist relevant stakeholders in the implementation of rights enshrined in international and European conventions and human rights standards, taking into account the case-law of the European Court of Human Rights. Namely:

a) to guide States in formulating legislation, policies, and other measures to promote the full range of children's rights in the digital environment and to consider the full range of ways in which the digital environment affects children's well-being and human rights;

b) facilitate the development, implementation, and monitoring by States of an integrated strategic and coordinated approach that reflects the approaches set out in these guidelines;

c) Ensure that States require businesses and other relevant stakeholders to be responsible for the observance of children's rights in the digital environment and to encourage them to uphold and promote such rights, and;

d) Ensure concerted action and cooperation at the national and international levels for the respect, protection, and realization of the rights of the child in the digital environment.

Therefore, expanding cooperation with international organizations and institutions should be one of the ways to increase the effectiveness of protection of children's rights and freedoms in the digital environment. At the same time, it should be noted that such work should be based not on copying the legal norms and experience of other countries, but on their thorough analysis, developing their approaches to child protection, taking into account national realities and existing legal mechanisms.

According to paragraph 21 of the Council of Europe Strategy on the Rights of the Child (2016-2021) (Council of Europe, 2016), the digital environment provides many opportunities for children through computers, game consoles, tablets, or smartphones. Internet access and digital literacy are already seen today as part of the rights of the child, in particular, to freedom of expression and education (Council of Europe, 2019).

Paragraph 51 of the annex to Recommendation CM / Rec (2018) 7 (Council of Europe, 2018) states that there are some issues related to the healthy development and well-being of children that may arise from the effects of the digital environment, including, but not limited to, the risks regarding damage from: 


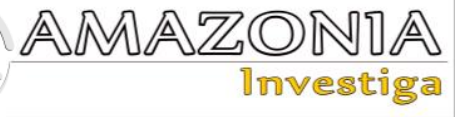

sexual exploitation and abuse, harassment for sexual purposes ("grooming", abuse), online recruitment of children to commit crimes, participation in extremist political or religious movements or for human trafficking (contact risks);

- $\quad$ humiliating and stereotypical portrayal and excessive sexualization of women and children; depicting and glorifying violence and self-harm, including suicide; derogatory, discriminatory or racist statements or incitement to such behavior; advertising, adult content (content risks);

- intimidation, harassment and other forms of harassment, distribution without the consent of sexual images, blackmail, hate speech, hacking, gambling, illegal downloading or other infringements of intellectual property rights, commercial exploitation (risks of conduct);

- overuse, sleep deprivation, and physical harm (health risks).

Of course, the above list of threats is not exhaustive. In the context of the above, it should be noted that changes in national legislation are not as dynamic as modern life requires, but assistance to children who have been victims of sexual violence should be provided today.

Today there is responsibility for the import, production, sale, and distribution of pornographic items (Article 301 of the Criminal Code of Ukraine), however today Criminal Code of Ukraine does not provide criminal liability for the use, acquisition, storage, download, access to materials depicting sexual violence against children.

In addition, national legislation does not provide definitions of such concepts as "grooming", "sextortion", etc. In such circumstances, the provisions of the Criminal Code of Ukraine (Law No. 2341-III, 2001) and the Criminal Procedure Code of Ukraine (Law No. 4651-VI, 2012) need to be improved.

Therefore, there is an urgent need to update the legal framework, which would meet modern requirements and create a basis for effective prevention of sexual violence against children and its prevention.

It is also important to note that the State Social Program "National Action Plan for the Implementation of the UN Convention on the Rights of the Child until 2021" (Resolution No. $453,2018)$ identifies one of the priorities of public authorities and civil society to create a safe information space for children, namely: ensuring the protection of personal data of the child and other confidential information about him; ensuring the safety of children in the information space; introduction of a system of socio-pedagogical work with parents on the safety of children in the information space.

Therefore, an essential area for preventing and combating sexual crimes against children should be a broad information campaign to cover, in particular: children's rights and threats to them in the digital environment; information systems on governmental and non-governmental institutions and organizations that carry out activities in this area and can provide professional advice and assistance to victims; national hotlines.

\section{Features of international cooperation in the investigation of sexual crimes against children}

There is great hope for international cooperation as a way to increase the effectiveness of combating sexual exploitation and sexual violence against children.

Thus, noting the expansion of cooperation with international institutions and organizations, it is worth emphasizing the capabilities of the International Criminal Police Organization "Interpol" to combat sexual exploitation and sexual violence against children. According to Art. 2 of the Constitution (Interpol, 1956) of this international organization, the purpose of its activities are:

- $\quad$ to ensure and promote the widest possible mutual assistance between all criminal police authorities within the current legislation of the country and in the spirit of the Universal Declaration of Human Rights;

- to establish and develop all institutions that can successfully contribute to the prevention and fight against crime.

We would like to pay special attention to Interpol databases, which provide the opportunity to collect and process information from anywhere (Brych, 2010).

It should be stated that the Interpol unit for crimes against children, which operates within the framework of the program to combat organized crime and new types of crimes, is directly responsible for combating crimes committed against children. The task of this unit is to coordinate and respond to crimes committed against children, especially those with signs of sexual violence and exploitation. The central part 
of the unit's work is the identification of victims. To this end, he maintains and administers the international database on child sexual exploitation (Popov, 2020).

International Child Sexual Exploitation database (Interpol, 2021) is intelligence and investigative tool that enables specialized investigators to share data on cases of sexual abuse of children. Using image and video comparison software, investigators can instantly establish links between victims, perpetrators, and crime scenes. Duplicate is not possible in this database. The investigator is always aware of finding or identifying several images in another country or of similar features of one image with others. Using an international database of child sexual exploitation, specialized investigators from more than 50 countries share information and data with their counterparts from around the world.

The activities of non-governmental organizations are extremely important in the context of combating sexual violence against children online. For example, the international organization ECPAT (2021) - End Child Prostitution in Asian Tourism is a worldwide network of NGOs working together to eliminate all forms of sexual exploitation of children, including sexual exploitation of children in prostitution, trade sites for sexual purposes (forced and early marriages, etc.), sexual exploitation online and sexual exploitation of children in the field of travel and tourism.

ECPAT has a special consultative status with the United Nations Economic and Social Union and is a member of a wide range of partnerships and alliances. Governments, NGOs, and other organizations often turn to ECPAT for technical expertise, recognizing its status as a superior international community of NGOs working to eliminate the sexual exploitation of children.

Particular attention should be paid to the activities of the Circle for Children (2021) - a non-profit organization, which is located in Brussels, and the work of which is aimed at promoting European activities to strengthen national children's protection systems. The principal purpose of the functioning of this organization is a combination of the experience of legislative and political events of the European Union with the experience of practitioners from the entire region to ensure improvement in the living standards of children. Child Circle contributes to expert consultations in the institutions and agencies of the European Union and the Council of Europe. The organization is a partner in regional projects providing leadership and tools to subjects to protect children from violence in Europe, in particular in the field of asylum and migration, sexual violence against children, and justice, adherent to children. Child Circle also conducts research, forms expert reports, and supports the development of capacity for children protection for organizations at the regional and national levels.

As we can see, the proposed ways to increase the effectiveness of combating sexual exploitation and sexual violence against children need to be implemented as soon as possible.

Problematic issues of international cooperation in the investigation of sexual crimes against children

It is crucial to bring national legislation into line with Ukraine to facilitate the implementation of the Lanzarote Convention (Council of Europe, 2007). Such implementation is an excellent opportunity to consider whether and how Ukraine can benefit from international experience and practical resources to provide all participants with procedures, tools, and skills to respond to child victims of violence and the proper realization of their rights.

It is also necessary to oblige the authorities to respond to violence against children at the national level in compliance with relevant international recommendations, including the Council of Europe Guidelines on Child-Friendly Justice (Council of Europe, 2010) and the General Comment of the UN Committee on the Rights of the Child No. 13 (United Nations, 2011). At the international level, actively promote and influence the reporting and monitoring of relevant Council of Europe bodies, including the Committee of the Parties to the Lanzarote Convention (Council of Europe, 2021a) and Group of Experts on Action against Trafficking in Human Beings (Council of Europe, 2021b), as well as the UN Committee on the Rights of the Child (United Nations, 2021).

The experience of European countries shows that there is neither a single way nor a single model for establishing effective international cooperation in the investigation of sexual crimes against children. At the same time, ratification of international and European law provides a necessary basis for the establishment and operation of law enforcement agencies, as it obliges the Member States to take concrete measures to prevent and combat violence against children, to protect children during criminal 


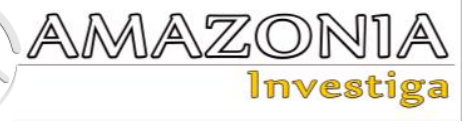

investigations and trials and to provide comprehensive and coordinated services for child victims of violence. However, further regulatory reform is needed to fully implement international standards. Effective interagency case management requires more detailed provisions and mechanisms for coordination, information exchange, and joint planning. The study repeatedly returns to the limited human resources available, as well as concerns that staff is not adequately trained in most disciplines. The main thing is that there is a will to implement the proposed changes in life.

In Ukraine, it is equally important to improve the mechanism of interaction between children's services, social protection institutions, centers of social services for families, children and youth, law enforcement agencies, educational institutions, health care facilities, which are defined in the Procedure for consideration of appeals and notifications child abuse or threat of its commission established by the Ministry of Social Policy of Ukraine, the Ministry of Internal Affairs of Ukraine, the Ministry of Education and Science of Ukraine, the Ministry of Health of Ukraine (Order No. 564/836/945/577, 2014).

With regard to further research, attention should be paid to the possibility of settling the issue of signing international agreements for cooperation in the investigation of sexual crimes against children. A more detailed study of the circumstances affecting the detection of sexual crimes against children should be paid in the condition of the one of the main problems of our time, which can put humanity on the verge of extinction - pandemic of the new virus COVID19. It is associated with an unprecedented narrowing of human rights and freedoms around the world (Tkalych, Safonchyk, \& Tolmachevska, 2020).

\section{Conclusions}

As a result of the study, a study of international cooperation in the investigation of sexual crimes against children was conducted and the following conclusions were made:

1. Victims of sexual crimes often remain invisible and vulnerable to further violence, with little help to recover from physical and mental trauma and bring perpetrators to justice. When sexual abuse is reported, children often become vulnerable.

2. Raising the level of awareness of parents and children, studying positive foreign experience and adapting it to national needs, expanding cooperation with international governmental and non-governmental organizations and institutions, developing and implementing specialized courses for professionals will promote activities aimed at combating the crimes under investigation and can be the first effective steps of society and the state in ensuring the protection of the rights and freedoms of children in this area.

3. Information on the prevalence of sexual violence against children in Europe indicates that the consequences of sexual violence are often associated with serious consequences for the physical and mental health and development of the child.

4. Sexual violence against children remains a severe problem in most countries under the guise of secrecy, stigma, and taboo. Only a small number of victims are revealed and often with a long delay. Registered cases do not always lead to a criminal investigation or trial. Underestimation of data continues to be a grave problem throughout Europe, including in Ukraine.

\section{Bibliographic references}

Brych, L.V. (2010). Crimes against sexual freedom and sexual integrity of a person under the laws of Ukraine. Lviv: Lviv. state University of Internal Affairs Affairs.

Charity Navigator (2021). The Circle for Children. Official web-site. Recovered from https://www.charitynavigator.org/ein/58603837 4.

Chornous, Y, Nikitina-Dudikova, H., Lepei, O., Antoniuk, A., \& Fridman-Kozachenko, M. (2021). Investigation of sexual crimes against children. Cuestiones Politicas, 39(68), 666-681. Council of Europe. (2007). Convention for the Protection of Children against Sexual Exploitation and Sexual Abuse. Recovered from https://www.coe.int/en/web/children/lanzaroteconvention

Council of Europe. (2010). Guidelines of the Committee of Ministers of the Council of Europe on child-friendly justice. Recovered from https://rm.coe.int/16804b2cf3.

Council of Europe. (2016). Council of Europe Strategy for the Rights of the Child (2016-2021). Recovered from https://www.coe.int/en/web/children/children-sstrategy.

Council of Europe. (2018). Recommendation CM / Rec (2018) 7 of the Committee of Ministers: Annex. Recovered from https://violenceagainstchildren.un.org/sites/viole nceagainstchildren.un.org/files/documents/politi cal_declarations/recomendation_of_the_commit 
tee_of_ministers_of_the_council_of_europe_to _member_states_on_guidelines_to_respect_prot ect_and_fulfil_the_rights_of_the_child_in_the digital_environment.pdf

Council of Europe. (2019). Protection of children from sexual exploitation and sexual violence. Recovered from https://rm.coe.int/cvavgujan2018-5-ua-web/16807874dc

Council of Europe. (2021a). Committee of the Parties to the Lanzarote Convention (Lanzarote Committee): official web-page. Recovered from https://www.coe.int/en/web/children/lanzarotecommittee\#\{\%2212441908\%22:[]\}

Council of Europe. (2021b). Group of Experts on Action against Trafficking in Human Beings (GRETA): official web-page. Recovered from https://www.coe.int/en/web/anti-human-

trafficking/greta

Deryagin, G.B. (2005). On the issue of preventing sexual violence. Forensic Library. Recovered from https://www.forensmed.ru/book.php?id=3400

ECPAT. (2021). Official web-site. Recovered from https://www.ecpat.org/.

Galay, A.O. (Ed.). (2014). International experience in preventing and combating domestic violence: a monograph. Kyiv: CST.

Humin, O.M. (2009). Features of criminological characteristics of the person in violent crimes. Legal Ukraine, 11, 102-108.

International Criminal Police Organization "Interpol". (1956). Constitution. Recovered from

https://www.interpol.int/content/download/590/f ile/Constitution \%20of\%20the\%20ICPO-

INTERPOL-EN.pdf

International Criminal Police Organization "Interpol". (2021). International Child Sexual Exploitation database. Recovered from https://www.interpol.int/Crimes/Crimes-againstchildren/International-Child-Sexual-

Exploitation-database.

Kharytonov, E., Kharytonova, O., Kolodin, D., \& Tkalych, M. (2020). The Covid-19 Pandemic and the Rights of the Individual in Terms of Private and Public Law. Ius Humani. Law Journal, 9(2), 225-250.

https://doi.org/https://doi.org/10.31207/ih.v9i2.2 53

Law No. 1296-IV. On the protection of public morality. Bulletin of the Verkhovna Rada of Ukraine, Kyiv, Ukraine, November 20, 2003. Recovered from https://zakon.rada.gov.ua/laws/show/1296$15 \#$ Text

Law No. 1819-VI. On Amendments to Certain Legislative Acts of Ukraine Concerning Counteraction to the Distribution of Child Pornography. Bulletin of the Verkhovna Rada of
Ukraine, Kyiv, Ukraine, January 20, 2010. Recovered from https://zakon.rada.gov.ua/laws/show/181917\#Text

Law No. 2229-VIII. On prevention and counteraction to domestic violence. Bulletin of the Verkhovna Rada of Ukraine, Kyiv, Ukraine, December 7, 2017. Recovered from https://zakon.rada.gov.ua/laws/show/222919\#Text

Law No. 2341-III. Criminal Code of Ukraine. Bulletin of the Verkhovna Rada of Ukraine, Kyiv, Ukraine, April 5, 2001. Recovered from https://zakon.rada.gov.ua/laws/show/234114/conv\#n2649

Law No. 254K/96-BP. Constitution of Ukraine. Bulletin of the Verkhovna Rada of Ukraine, Kyiv, Ukraine, June 28, 1996. Recovered from https://zakon.rada.gov.ua/laws/show/254\%D0\% BA/96-\%D0\%B2\%D1\%80\#Text.

Law No. 2866-IV. On Ensuring Equal Rights and Opportunities for Women and Men. Bulletin of the Verkhovna Rada of Ukraine, Kyiv, Ukraine, September 8, 2005. Recovered from https://zakon.rada.gov.ua/laws/show/286615\#Text

Law No. 2402-III. On Child Protection. Bulletin of the Verkhovna Rada of Ukraine, Kyiv, Ukraine, June 16, 2001. Recovered from https://zakon.rada.gov.ua/laws/show/2402-14

Law No. 4651-VI. Criminal Procedure Code of Ukraine. Bulletin of the Verkhovna Rada of Ukraine, Kyiv, Ukraine, April 13, 2012. Recovered from https://zakon.rada.gov.ua/laws/show/465117\#Text

Melnik, M.I., \& Khavronyuk, M.I. (Eds.). (2018). Scientific and practical commentary on the Criminal Code of Ukraine. Kyiv: Legal opinion. Recovered from https://dakor.kiev.ua/wpcontent/uploads/naukovo-praktychnyjkomentar-kryminalnoho-kodeksu-ukrainy.pdf Ministry of Internal Affairs of Ukraine. (2021). Status and structure of crime in Ukraine. Statistics of the Ministry of Internal Affairs of Ukraine. Recovered from https://mvs.gov.ua/uk/activity/statistika

Order No. 564/836/945/577. Procedure for consideration of appeals and notifications child abuse or threat of its commission established by the Ministry of Social Policy of Ukraine, the Ministry of Internal Affairs of Ukraine, the Ministry of Education and Science of Ukraine, the Ministry of Health of Ukraine. Bulletin of the Verkhovna Rada of Ukraine, Kyiv, Ukraine, August 19, 2014. Recovered from https://zakon.rada.gov.ua/laws/show/z110514\#Text. 


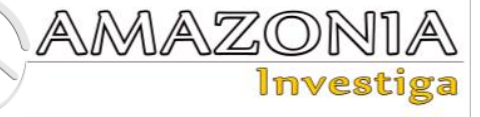

Order No. 650. About the statement of the Instruction on the organization of activity of district police officers. Bulletin of the Verkhovna Rada of Ukraine, Kyiv, Ukraine, July 28, 2017. Recovered from https://zakon.rada.gov.ua/laws/show/z104117\#Text

Popov, G. (2020). Sexual exploitation and sexual violence against children using electronic means of communication: urgent countermeasures. Site of the Higher School of Advocacy of NAAU. Recovered from https://www.hsa.org.ua/blog/seksualnaekspluatatsiya-ta-seksualne-nasylstvo-stosovnoditej-iz-vykorystannyam-elektronnyh-zasobivkomunikatsiyi-nevidkladni-zahody-z-protydiyi/ Resolution No. 453. On approval of the State Social Program "National Action Plan for the Implementation of the UN Convention on the Rights of the Child" until 2021. Bulletin of the Verkhovna Rada of Ukraine, Kyiv, Ukraine. Recovered from https://zakon.rada.gov.ua/laws/show/453-2018$\% \mathrm{D} 0 \% \mathrm{BF} \# \mathrm{Text}$

Romantsova, S.V. (2013). Criminological characteristics of persons who commit sexual violence against children. Scientific Bulletin of Kherson State University: Legal Sciences, 3, 109-112.

Schmidt, B.D. (2010). Definition of sexual abuse of children. Child abuse and neglect: visual diagnosis of injuries and poor weight gain. Recovered from http://www.myshared.ru/slide/573848/ State Statistics Service of Ukraine. (2019). Crime in Ukraine. Kyiv: State Statistics Service of
Ukraine. Recovered from http://www.ukrstat.gov.ua/druk/publicat/kat_u/2 019/zb/12/zb_ru1ch2019.pdf

Tatsia, V.Ya., Borisova, B.I., \& Tyutyugina V.I. (2015). Criminal law of Ukraine. Kharkiv: Law. Tkalych, M., Safonchyk, O., \& Tolmachevska, Y. (2020). Private Law and human rights: New realities. DIXI, 22(2), 1-12. DOI: https://doi.org/10.16925/2357-5891.2020.02.04 Tulyakov, V.A. (2001). Violence and children. Problems of combating violent crime in Ukraine. Kharkiv: Lestvytsa Marii

United Nations. (1950). Convention for the Protection of Human Rights and Fundamental Freedoms. Recovered from https://www.echr.coe.int/documents/convention _eng.pdf

United Nations. (1989). Convention on the Rights of the Child. Recovered from https://www.ohchr.org/en/professionalinterest/p ages/crc.aspx

United Nations. (2011). General comment No. 13 (2011). The right of the child to freedom from all forms of violence. Recovered from https://www.refworld.org/docid/4e6da4922.html United Nations. (2021). Committee on the Rights of the Child: official web-page. Recovered from https://www.ohchr.org/en/hrbodies/crc/pages/cr cindex.aspx

Zhuravel, T.V. (2013). Socio-pedagogical work on prevention of violence against children. Social pedagogy, 1, 197-209. Recovered from https://elibrary.kubg.edu.ua/id/eprint/5125/1/T_ Zhuravel_SPRPND_KSP\%26SR_IL.pdf 